\title{
Short Communication: Herpetofauna diversity, potential ecotourism in Mount Galunggung, West Java, Indonesia
}

\author{
AWAL RIYANTO ${ }^{1,2, \vartheta}$, TAUFAN NURZAMAN SULAEMAN ${ }^{2, v v}$, NUR RACHMAN ${ }^{2}$, \\ DIKI MUHAMAD CHAIDIR ${ }^{3, v v v}$, WAHYU TRILAKSONO ${ }^{1}$, ACHMAD FARAJALLAH ${ }^{2, v v v v}$ \\ ${ }^{1}$ Museum Zoologicum Bogoriense, Research Center for Biology. Widyasatwaloka Building, Jl. Raya Jakarta Bogor Km. 46, Cibinong, Bogor 16911, \\ West Java, Indonesia. Tel.: +62-21-8765056, `email: awal.riyanto@lipi.go.id, awal_riyanto@ apps.ipb.ac.id \\ ${ }^{2}$ Program of Animal Biosciences, Graduate School, Institut Pertanian Bogor. Jl. Raya Darmaga, IPB Campus Darmaga, Bogor 16680, West Java,

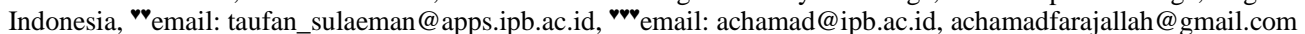 \\ ${ }^{3}$ Department of Biology Education, Faculty of Teacher Training and Education, Universitas Siliwangi. Jl. Siliwangi No.24, Kahuripan, Tawang, \\ Tasikmalaya 46115, West Java, Indonesia, ${ }^{\text {vwץ }}$ email: dikimc@unsil.ac.id
}

Manuscript received: 25 February 2019. Revision accepted: 28 March 2019.

\begin{abstract}
Riyanto A, Sulaeman TN, Rachman N, Chaidir DM, Trilaksono W, Farajallah A. 2019. Short Communication: Herpetofauna diversity, potential ecotourism in Mount Galunggung, West Java, Indonesia. Biodiversitas 20: 1173-1179. Here we provide a list of herpetofauna at Mount Galunggung, West Java, Indonesia as potential biodiversity for ecotourism. Data were collected from our observations in March 2013 and November 2018 using visual and acoustic encounter search methods in the three zones (hot springs, craters, and foothills) on the nature tourism destination of the mount. We revealed 35 species of herpetofauna and their local distribution on these zones. Even though the diversity of herpetofauna has not been observed completely, we suggested that the biodiversity data from this zone should be used as the basic capital in turning nature tourism base into ecotourism base, so that it would provide more benefits to biodiversity conservation itself and to the local community.
\end{abstract}

Keywords: Acoustic, ecotourism, herpetofauna, Mt. Galunggung, visual

\section{INTRODUCTION}

Ecotourism has been worldwide implemented on conservation (Loubseer et al. 2001) and development tool because it provides benefits both in conservation and economic. Theoretically, the distribution of some benefits to local people will give them an incentive to protect the natural area that draw tourist to be more (Charnley 2005). The protection of natural areas, high quality tourism experiences provision and economic stimulation for in local scope, resources provision for conservation, environmental education and local empowerment are the fundamental functions of ecotourism. The effectiveness of an ecotourism site is represented by degree to which these variables are functioning, or have the potential to function. In other words, ecotourism should develop synergistic relationships between tourism, biodiversity, and local communities, facilitated by appropriate management strategy (Wall and Ross 1999).

Indonesia with approximately 17,000 islands and possesses one of the world's greatest expanses of tropical forest and continuous coral systems. At least $10 \%$ of the Earth's tropical moist forest biome and the second richest expanse of tropical rainforest in the world next to Brazil is owned by Indonesia (Whitmore 1990). The complexity of nature and geological origins has made many of its islands supporting unique flora and fauna found nowhere else in the world. In contrast, it also possesses the greatest number of species threatened with extinction and destroying its forests is faster than any other country in the world. Human population is growing over 200 million with consequence of the demands for food, timber and other forest product that will result in the continued destruction of the forest due to agricultural production, shifting cultivation and associated fires, urban development, and mining (Ross and Wall 1999).

Gunung (Mount) Galunggung is one of the destinations of nature tourism in Indonesia. The mount is an active volcano which had latest eruption in 1982-1983 (Katili and Sudrajat 1983; Malingreau and Kaswanda 1986; Dana 2010). At least there are two kinds of nature tourism in this mount namely hot springs and death crater. This mount becomes the most visited nature tourism in the city (Disparbud 2016). Regarding the biodiversity, this mount has high potency, and several authors have reported it. Gunung Galunggung is inhabited by about 213 plant species (Zuhri et al. 2015) and hypotheses of these species number might be increased due to its structure vegetation which hasn't reached its climax yet (Suryana et al. 2018). This landscape supports the life of 20 species of fish (Haryono 2015), 39 species of birds (Widodo 2014) and 67 species of butterflies (Imam 2014). However, there was no reported data on herpetofauna species. Here, we revealed and thus provided the herpetofauna diversity of this area. These biodiversity data should be used as the basic capital in changing nature tourism into ecotourism. 


\section{MATERIALS AND METHODS}

\section{Study area}

Our study area is located in tourism route on Gunung Galunggung, West Java, Indonesia. Administratively, it is included in Tasikmalaya District of West Java Province, Indonesia (Figure 1). This route lay on east slope of this mount. The study area was divided into three zones; (i) hot springs, (ii) foothill, and (iii) death crater. Hot springs zone are including several habitat types such as hot springs, shrub, small stream and waterfall (Figure 2.A). In foothill, it included habitat types of pines forest, river, and shurb (Figure 2.B). Meanwhile, the death crater is body water with border of sand come from the last eruption which was overgrown with grasses (Figure 2.C).

\section{Data collection}

Visual Encounter Survey (VES) and Acoustic Encounter Survey (AES) were applied for opportunistic searching the herpetofauna in the target areas. These surveys were conducted in March 2013 and November 2018.

\section{Nomenclature}

We followed Rooij $(1915$, 1917), Manthey \& Grossmann (1997), Mausfeld et al. (2002), and Uetz\& Hošek (2019) literature's for taxonomy and nomenclature of reptiles; and for the amphibians by followed Kampen (1923), Manthey \& Grossmann (1997), Iskandar (1998), and Frost (2019).

\section{Conservation status}

The national conservation status of each species was checked based on national regulation (PP. 7/1999 and Permen P.92/MENLHK/SETJEN/KUM.1/8/2018), meanwhile, for international conservation status, The IUCN Red List of the Threatened Species (IUCN 2019) and Appendices of CITES (2019) was followed.

\section{Data analysis}

Data were tabulated in an existence matrix (Table 1) and then plotted in a Venn diagram to determine the distribution pattern of species in this study area. We also compared our total number of species from this study to nature, ecotourism and mountains data in Java found on available literature.

\section{RESULTS AND DISCUSSION}

\section{Species richness, local distribution, and herping}

A total of 35 herpetofauna species were recorded (Table 1) comprising of 14 frogs, 10 lizards and 11 snakes. Of these, four anurans are endemic to Java i.e. Huia masonii (Javan torrent frog), Megophrys montana (Javan hornet frog), Microhyla achatina (Javan chorus frog) and Limnonectes kuhlii (Kuhl's creek frog). No species were listed in protected animal under national regulation. One snake has listed in CITES app. II, i.e. Malayopython reticulatus (Reticulated python), meanwhile 25 species were listed in IUCN Redlist in which 24 species were categorized as Least Concern (LC) and one species, Rhacophorus reinwardtii (Reinwardti's frog) was categorized as Near Threatened (NT). Unidentified and possibly undescribed lizard species of unusual specimen will be referred to the genus Cyrtodactylus and Tytthoscinctus.

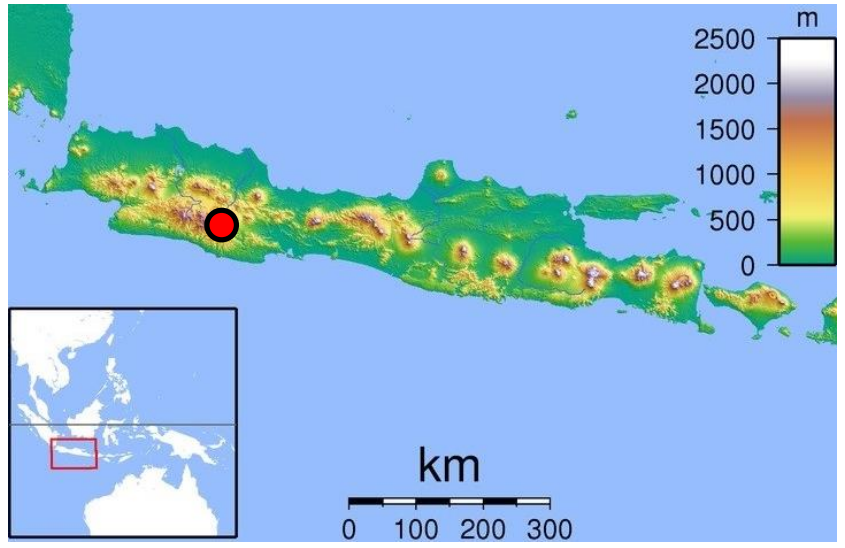

Figure 1. Location of Gunung Galunggung nature tourism destination (red circle) in West Java, Indonesia. Map source from Wikipedia.

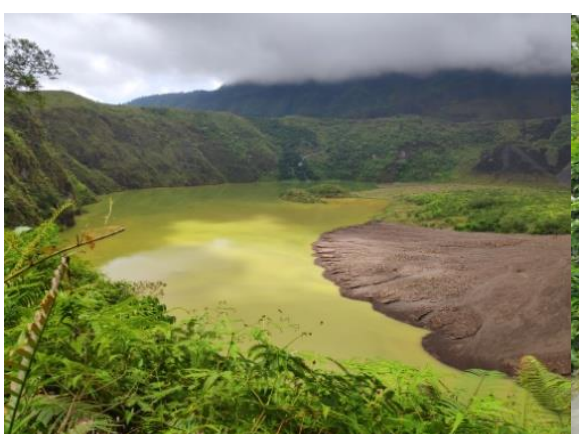

A

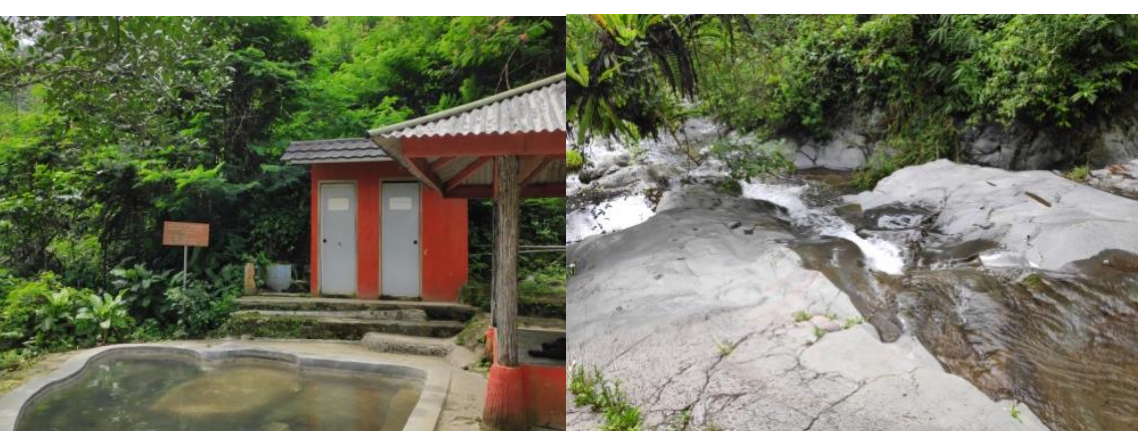

B
C

Figure 2. Habitat type in three observation sites in Galunggung, Tasikmalaya, West Java, Indonesia. A. Crater area, B. Hot springs, and C. Gado Bangkong stream in the foothill 
The species richness of herpetofauna in Gunung Galunggung nature tourism destination is relatively high compared to other mount and nature tourism destinations in Java. The number of species is similar to Baturaden nature tourism at southern slope of Mount Slamet in Central Java, Indonesia (Riyanto 2010) and Purbalingga in eastern slope of Mount Slamet (Riyanto and Trilaksono 2012). Although the number of species is still lower than Gunung Ciremai National Park in West Java (35 versus 46 species) (Riyanto 2011) but it is higher than that in the upstream river of Mount Sindoro (35 versus 14 species) (Subeno 2018) and Coban Putri nature tourism in East Java (35 versus 10 species) (Hidayah et al. 2018).

Based on our data, it seems that the hot springs zone is the area with the most species (26 species), followed by death crater zone (15 species) and foothill zone (11 species). There were four species found in all zones, i.e. Duttaphrynus melanostictus (Asian common toad), Limnonectes microdiscus (Indonesia Wart Frog), Polypedates leucomystax (Common tree frog) and Cyrtodactylus sp. (Bent-toed gecko). Three species only found at death crater zone were Ingerophrynus biporcatus, Calamaria sp. and Elapoidis fusca (Dark grey ground snake), whereas Ahaetulla mycterizans (Malayan green whipsnake), Xenodremus javanicus (Dragon snake) and Trimeresurus puniceus (Flat-nosed pitviper) were only found at foothill zone. Resume of the local distribution pattern of the herpetofauna among three zones is illustrated in Figure 3.

In this study, the area with highest species richness was in hot springs zone. It might happen because this zone contains more varied habitat types such as hot springs, shrub, small stream and waterfall which were more diverse in microhabitat and patches for supporting the life of herpetofauna. The herpetofauna diversity of this nature tourism destination is a potential and a challenge to create a herpetofauna-based ecotourism base. Furthermore, the habitus, sound, and behavior of these faunal groups are interesting, and to find them in the wild gives an adventurous sensation. We promote a herping activity as one of ecotourism forms which should be created in Gunung Galunggung. The herping means an activity to look for and watch the herpetofauna at night or day on the certain habitat types by a limited number of people, and this activity should have no negative impact on the herpetofauna. This group of tourists is guided by a tour guide from the local people who have been provided with knowledge about herpetofauna and conservation. The profiles of several species are presented in Figure 4-7.

\section{From nature into ecotourism}

One critical issue in ecotourism is the success of promoting the well being of both local peoples and their environments. For this, Scheyvens (1999) suggested four levels of empowerment in a framework, such as psychological, social, political and economic. Based on this framework, the impacts of ecotourism ventures on local communities, the attempts to emphasize the importance of local communities having some control over it and the benefits for sharing ecotourism initiatives in their area can be analyzed.
In the case of Gunung Galunggung tourism, which is still on the nature-based tourist destination, and in order to open the opportunity to shift it into ecotourism-based one, we agree with that empowerment framework. We suggested that among stakeholders in this destination tourism which involves local governments, the ministry of forestry, local people, local NGO, and academics an integrated manner to run that framework should be accommodated.

Table 1. Checklist of herpetofauna and their local distribution in Gunung Galunggung, Tasikmalaya, West Java, Indonesia

\begin{tabular}{|c|c|c|c|c|c|}
\hline \multirow[b]{2}{*}{ Species } & \multicolumn{3}{|c|}{ Zones } & \multicolumn{2}{|c|}{ Status } \\
\hline & 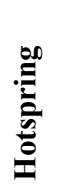 & 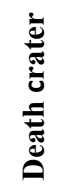 & 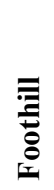 & 忌 & \\
\hline \multicolumn{6}{|l|}{ Bufonidae } \\
\hline Ingerophrynus biporcatus & 0 & 1 & 0 & $\mathrm{LC}$ & \\
\hline Phrynoidis aspera & 0 & 1 & 1 & $\mathrm{LC}$ & - \\
\hline Duttaphrynus melanostictus & 1 & 1 & 1 & $\mathrm{LC}$ & - \\
\hline \multicolumn{6}{|l|}{ Dicroglossidae } \\
\hline Fejervarya limnocharis & 1 & 0 & 0 & $\mathrm{LC}$ & - \\
\hline Limnonectes kuhlii & 1 & 0 & 1 & $\mathrm{LC}$ & - \\
\hline Limnonectes macrodon & 1 & 0 & 0 & $\mathrm{LC}$ & - \\
\hline Limnonectes microdiscus & 1 & 1 & 1 & $\mathrm{LC}$ & - \\
\hline \multicolumn{6}{|l|}{ Megophrydae } \\
\hline Megophrys montana & 1 & 0 & 0 & $\mathrm{LC}$ & - \\
\hline \multicolumn{6}{|l|}{ Microhylidae } \\
\hline Microhyla achatina & 1 & 1 & 0 & $\mathrm{LC}$ & - \\
\hline \multicolumn{6}{|l|}{ Ranidae } \\
\hline Amnirana nicobariensis & 1 & 1 & 0 & $\mathrm{LC}$ & - \\
\hline Chalcorana chalconota & 1 & 0 & 0 & $\mathrm{LC}$ & - \\
\hline Odorrana hosii & 0 & 1 & 1 & $\mathrm{LC}$ & - \\
\hline \multicolumn{6}{|l|}{ Rhacophoridae } \\
\hline Polypedates leucomystax & 1 & 1 & 1 & $\mathrm{LC}$ & - \\
\hline Rhacophorus reinwardtii & 1 & 1 & 0 & NT & . \\
\hline \multicolumn{6}{|l|}{ Agamidae } \\
\hline Bronchocela jubata & 1 & 0 & 0 & $\mathrm{LC}$ & - \\
\hline Gonocephalus chamaeleontinus & 1 & 0 & 0 & - & - \\
\hline Gonocephalus kuhlii & 1 & 0 & 0 & - & - \\
\hline \multicolumn{6}{|l|}{ Gekkonidae } \\
\hline Cyrtodactylus sp & 1 & 1 & 1 & - & - \\
\hline Gehyra mutilata & 1 & 0 & 0 & - & - \\
\hline Hemidactylus frenatus & 1 & 1 & 0 & $\mathrm{LC}$ & - \\
\hline Hemidactylus platyurus & 1 & 0 & 0 & - & - \\
\hline \multicolumn{6}{|l|}{ Lacertidae } \\
\hline Takydromus sexlineatus & 1 & 0 & 0 & $\mathrm{LC}$ & - \\
\hline \multicolumn{6}{|l|}{ Scincidae } \\
\hline Eutropis multifasciata & 1 & 1 & 0 & - & - \\
\hline Tytthoscintus sp. & 1 & 0 & 0 & - & - \\
\hline \multicolumn{6}{|l|}{ Colubridae } \\
\hline Ahaetulla prasina & 1 & 0 & 0 & $\mathrm{LC}$ & - \\
\hline Ahaetulla mycterizans & 0 & 0 & 1 & $\mathrm{LC}$ & - \\
\hline Calamaria sp. & 0 & 1 & 0 & - & - \\
\hline Dendrelaphis pictus & 1 & 0 & 0 & _ & - \\
\hline Elapoidis fusca & 0 & 1 & 0 & $\mathrm{LC}$ & - \\
\hline Ptyas korros & 1 & 0 & 0 & - & - \\
\hline Rhabdophis subminiatus & 1 & 0 & 0 & $\mathrm{LC}$ & - \\
\hline Xenodermus javanicus & 0 & 0 & 1 & $\mathrm{LC}$ & - \\
\hline \multicolumn{6}{|l|}{ Phytonidae } \\
\hline Malayophyton reticulatus & 1 & 1 & 0 & $\mathrm{LC}$ & II \\
\hline \multicolumn{6}{|l|}{ Viperidae } \\
\hline Trimeresurus albolabris & 1 & 0 & 1 & $\mathrm{LC}$ & - \\
\hline Trimeresurus puniceus & 0 & 0 & 1 & $\mathrm{LC}$ & \\
\hline Total & 26 & 15 & 11 & & \\
\hline
\end{tabular}

threatened, II: appendix II. -: not listed. 


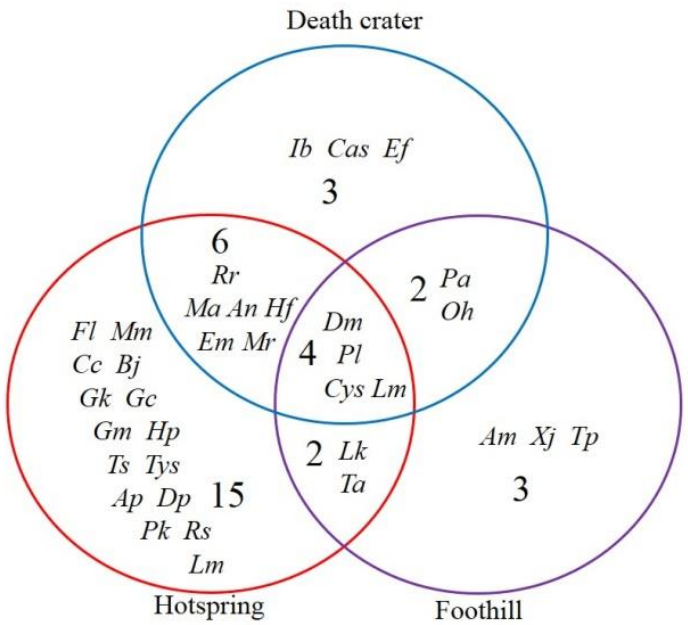

Figure 3. A Venn diagram showed the species distribution among three zones surveyed in Gunung Galunggung nature destination. Ib-Ingerophrynus biporcatus, Cas-Calamaria sp., Ef-Elaphoidis fusca, Am-Ahaetulla mycterizans, Tp-Tremeresurus punicius, XjXenodremus javanicus, Fl-Fejervarya limnocharis, $\mathrm{Mm}$ Megophrys montana, Cc-Chalcorana chalconota, Bj-Bronchocela jubata, Gk-Gonocephalus kuhlii, Gc-G. chamaeleontinus, LmLimnonectes macrodon, Hp-Hemidactylus platyurus, Gm-Gehyra mutilata, Ts-Takydromus sexlineatus, Tys-Tytthoscintus sp., ApAhaetulla prasina, Dp-Dendrelaphis pictus, Pk-Ptyas korros, RsRhabdophis subminiatus, Rr-Rhacophorus reindwardtii, MaMicrohylla achatina, An-Amnirana nicobariensis, HfHemidactylus frenatus, Em-Eutropis mulatifasciata, $\mathrm{Mr}$ Malayohpyton reticulatus, Pa-Phrynoidis aspera, Oh-Odorrana hossi, Lk-Limnonectes kuhlii, Ta-Trimeresurus albolabris, DmDuttaphrynus melanostictus, Pl-Polypedates leucomystax, CysCyrtodactylus sp. and Lm-Limnonectes microdiscus.

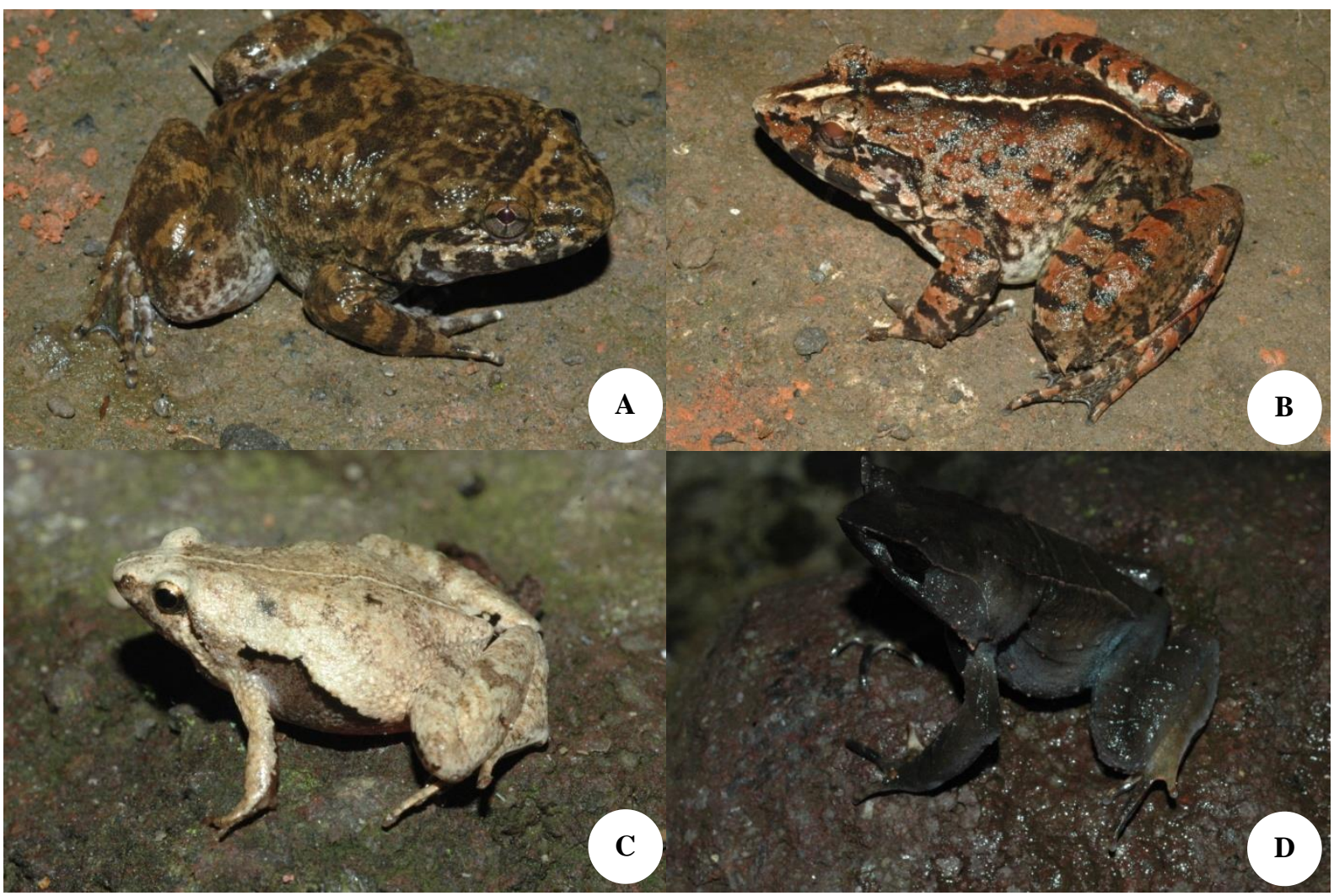

Figure 4. Some frogs found in Mt. Galunggung nature tourism destination. A. Limnonectes kuhlii, B. Limnonectes macrodon, C. Microhyla achatina, and D. Megophrys montana. Photographs by A. Riyanto 


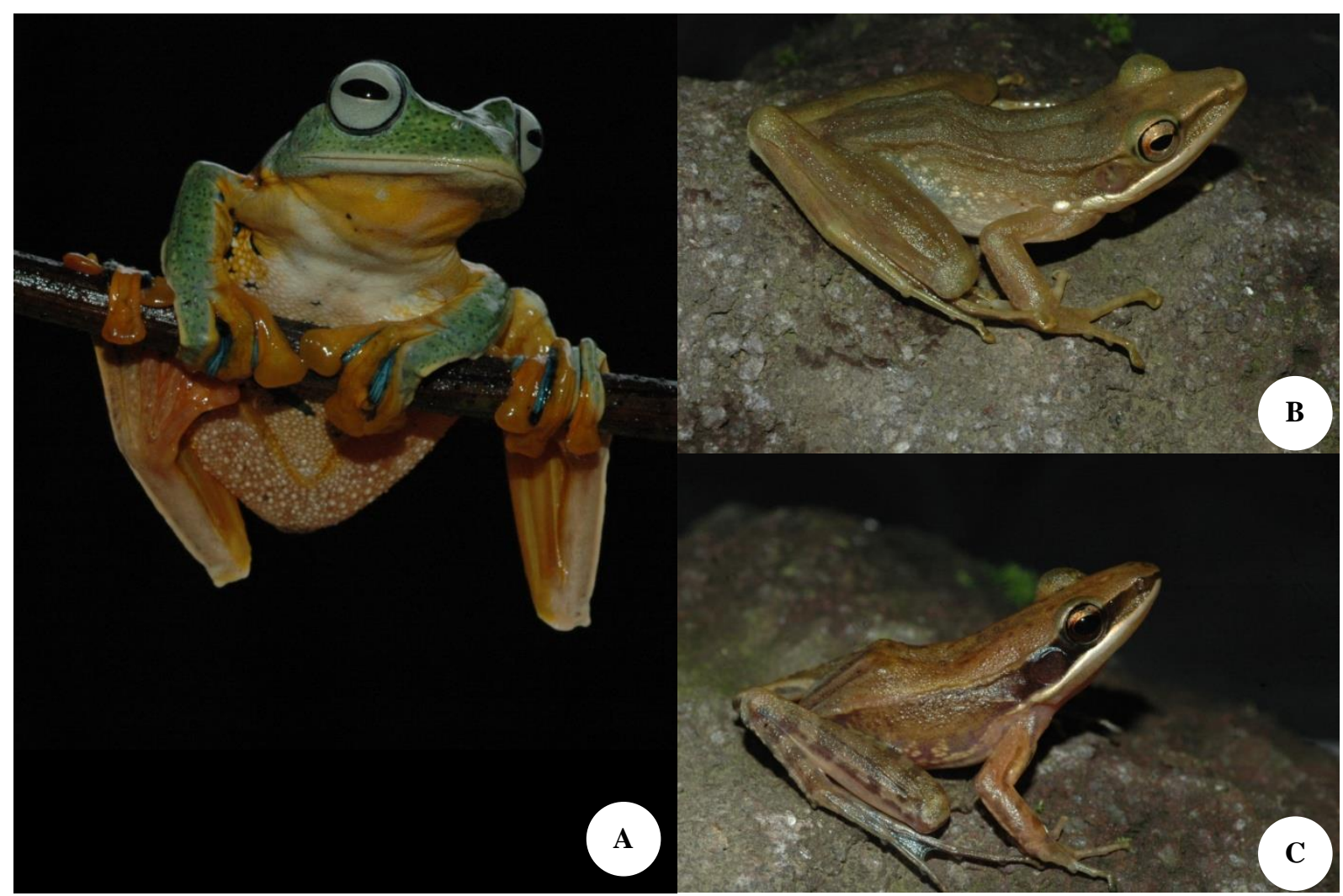

Figure 5. Some frogs which were in Mt. Galunggung nature tourism destination. A. Rhacophorus reinwardtii, B. Chalcorana chalconota, and C. Amnirana nicobariensis. Photographs by A. Riyanto

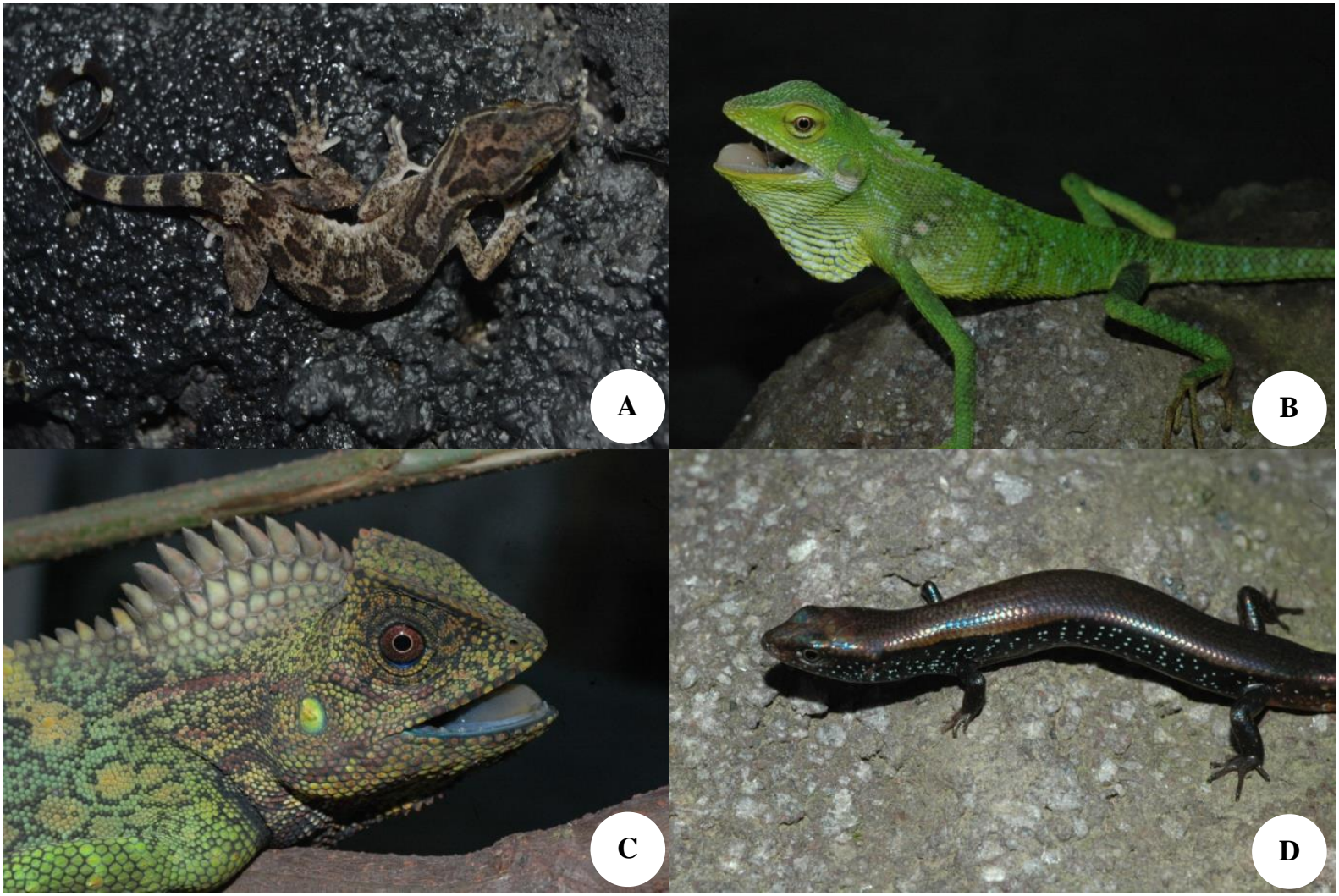

Figure 6. Some lizards found in Mt. Galunggung nature tourism destination. A. Cyrtodactylus sp., B. Bronchocela jubata, C. Gonocephalus chamaeleontinus, and D. Tytthoscintus sp. Photographs by A. Riyanto 


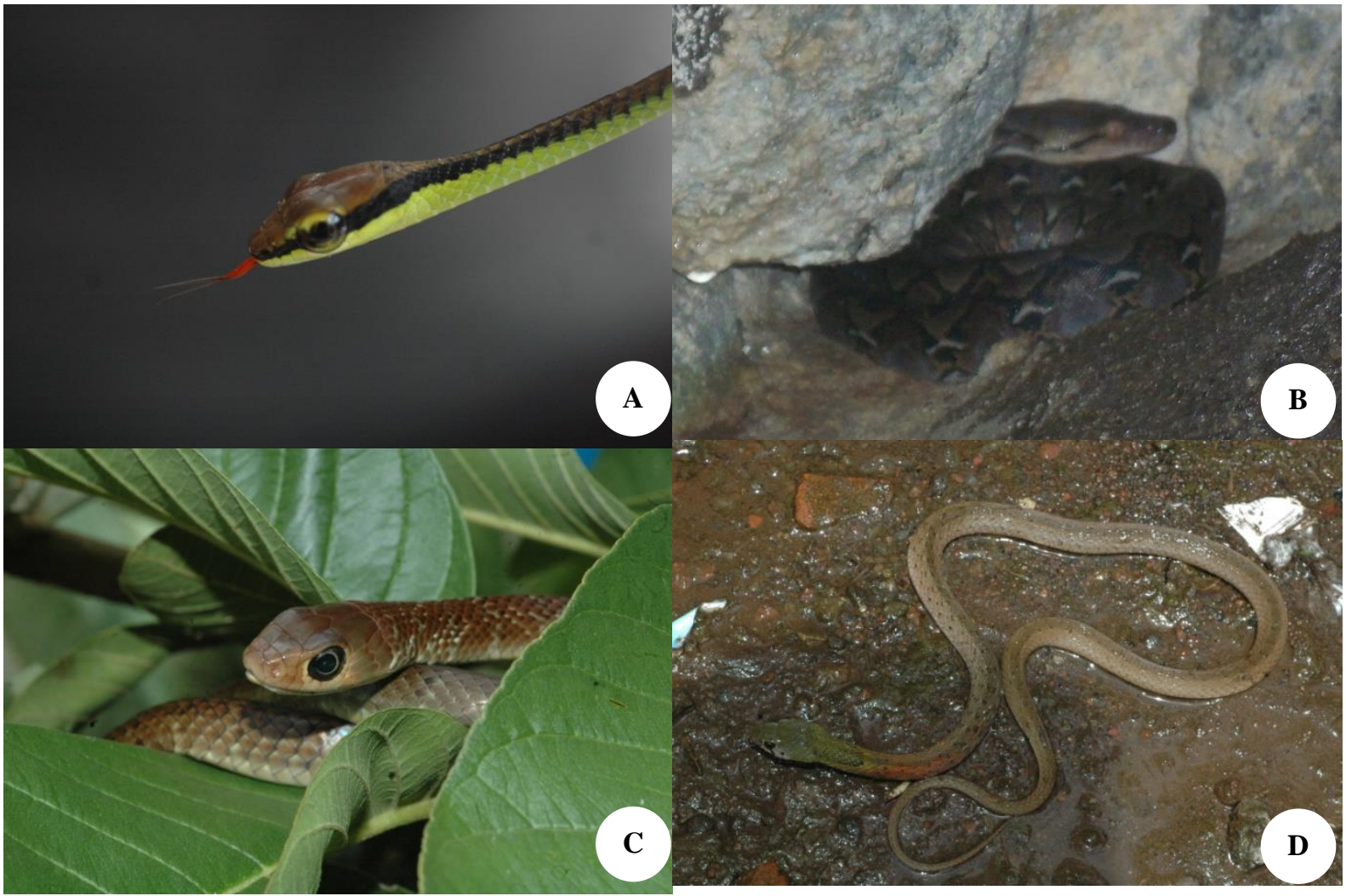

Figure 7. Some snakes found in Mt. Galunggung nature tourism destination. A. Dendrelaphis pictus, B. Malayophyton reticulatus, C. Ptyas korros, and D. Rhabdophis subminiatus. Photographs by A. Riyanto

\section{REFERENCES}

CITES. 2019. CITES appendices I, II and III http://www.cites.org/eng/app/appendices.php. [28 March 2019]

Dana. 2010. Gunung Galunggung, konservasi wilayah Bukit Sepuluh Ribu, peran dan fungsinya terhadap Kota Tasikmalaya. Bulletin Vulkanologi dan Bencana Geologi 5 (1): 25-32. [Indonesia]

Disparbud. 2016. Data Arus Kunjungan Wisatawan. Database. Dinas Pariwisata dan Kebudayaan Kabupaten Tasikmalaya, Singaparna [Indonesia]

Eprilurahman R, Kusuma KI. 2011. Amfibi dan reptil di lereng selatan Gunung Api Merapi sebelum erupsi 2010. Berkala Ilmiah Biologi 10 (1): 1-8. [Indonesia]

Frost DR. 2019. Amphibian species of the World: an Online Reference. $\begin{array}{llll}\text { Version } & 6.0 & \text { Electronic } & \text { Database }\end{array}$ http://research.amnh.org/herpetology/amphibia/index.html. [17 March 2019].

Haryono. 2015. Iktiofauna di perairan kawasan Gunung Galunggung Kabupaten Tasikamalaya, Jawa Barat. Proceedings of $8^{\text {th }}$ National Seminary of Fish. Bogor. 3-4 Juni 2014. [Indonesia]

Hidayah A, Hanifa BF, Devi SR, Septiadi L, Alwi MZ, Afifudin. 2018. Keanekaragaman Herpetofauna di Kawasan Wisata Alam Coban Putri Desa Tlekung, Kecamatan Junrejo, Kota Batu, Jawa Timur. Prosiding Seminar Nasional VI Hayati, Universitas Nusantara PGRI Kediri, 4 Agustus 2018. [Indonesia]

Imam D. 2014. Kelimpahan dan keanekaragaman kupu-kupu di Kabupaten Tasikmalaya, Jawa Barat. Unpublished Bach. Thesis, Indonesia University of Education.

Iskandar DT. 1998. The amphibians of Java and Bali. Research and Development Centre for Biology-LIPI-GEF-Biodiversity Collection Project, Bogor.

IUCN. 2019. The IUCN Red List of Threatened Species. Version 2019-1. https://www.iucnredlist.org [28 March 2019]
Kampen PNvan. 1923. The amphibians of the Indo-Australian Archipelagos. E.J. Brill Ltd., Leiden.

Katili JA, Sudrajat A. 1983. The 1982-1983 Galunggung Eruption. Departement of Mines and Energy, Jakarta.

Malingreau JP, Kaswanda. 1986. Monitoring volcanic eruptions in Indonesia using weather satellite data: The Colo eruption of July 28, 1983. J Volcanol Geotherm Res 27 (1-2):179-194.

Manthey U, Grossman W. 1997. Amphibien und reptilien sudostasiens. Nature \& Tier-Verlag, Munster.

Mausfeld P, Schmitz A, Bohme W, Misof B, Vricradic D, Rocha CFD. 2002. Phylogenetic affinities of Mabuya atlantica Schmidt, 1945, endemic to the Atlantic Ocean Archipelago of Fernando de Noronha (Brazil): Necessity of partitioning the genus Mabuya Fritzinger, 1826 (Scincidae: Lygosoma). Zoologischer Anzeiger 241: 281-293.

Mittermeier RA, Mittermeier G C, Robles GP. 1997. Megadiversity: Earth's biologically wealthiest nations. Cemex Monterrey, Mexico.

P.92. 2018. Peraturan Menteri Lingkungan Hidup Dan Kehutanan Tentang Perubahan Atas Peraturan Menteri Lingkungan Hidup Dan Kehutanan Nomor P.20/MENLHK/SETJEN/KUM.1/6/2018 Tentang Jenis Tumbuhan Dan Satwa Yang Dilindungi. [Indonesian]

PP 7. 1999. Peraturan Pemerintah Republik Indonesia Tentang Pengawetan Jenis Tumbuhan dan Satwa. [Indonesian]

Riyanto A, Trilaksono W. 2012. Komunitas herpetofauna di lereng timur Gunung Slamet, Jawa Tengah. In: Maryanto I, Noerdjito M, Partomiharjo T (eds) Ekologi Gunung Slamet: Ekologi, klimatologi, biodversitas dan dinamika sosial. Pusat Penelitian Biologi-LIPI, Bogor \& Universitas Jenderal Soedirman, Banyumas. [Indonesian]

Riyanto A. 2010. Komunitas herpetofauna dan potensi bagi sektor ekowisata pada kawasan Ketenger-Baturaden di selatan kaki Gunung Slamet, Jawa Tengah. Biosfera 27 (2):60-67. [Indonesian]

Riyanto A. 2011. Herpetofaunal community structure and habitat associations in Gunung Ciremai National Park, West Java, Indonesia. Biodiversitas 12 (1): 3844 . 
Rooij ND. 1915. The reptiles of the Indo-Australian Archipelago. E. J. Brill, Leiden.

Rooij ND. 1917. The reptiles of the Indo Australian archipelago I (Ophidia). E.J. Brill, Leiden.

Scheyvens R. 1990. Case study: Ecotourism and the empowerment of local communities. Tourism Manag 20: 245-249.

Subeno. 2018. Distribusi dan keanekaragaman herpetofauna di hulu sungai Gunung Sindoro, Jawa Tengah. Jurnal Ilmu Kehutanan 12: 4051. [Indonesian]

Suryana, Iskandar J, Parikesit, Partasasmita R, Irawan B. 2018. Struktur vegetasi kawasan hutan pada zona ketinggian berbeda di kawasan Gunung Galunggung Kabupaten Tasikmalaya Jawa Barat. Jurnal Ilmu Lingkungan 16 (2): 130-135.[Indonesian]
Uetz P, Hošek J. 2019. The Reptile Database. http://reptiledatabase.reptarium.cz/advanced_search? genus=cyrtodactylus\&submit= Search. [13 March 2019]

Widodo W. 2014. Population and dispersion pattern of species of birds at the galunggung tourism forest, Tasikmalaya, West Java. Biosaintifika 6 (1): 29-37. [Indonesian]

Zuhri M, Wiriadinata H, Astuti RS, Hadiwaluyo S, Syamsudin. 2015. Eksplorasi flora di kawasan Gunung Galunggung, Jawa Barat untuk pengayaan koleksi Kebun Raya Kuningan, Jawa Barat. Abstrak Seminar Nasional Masyarakat Biodiversitas Indonesia, Kampus ITB Jatinangor, 13 Juni 2015. [Indonesian] 